\title{
CONTEMPORARY PROBLEMS OCCURRING IN MULTICULTURAL TEAMS, EXEMPLIFIED BY THE OPINIONS OF EMPLOYEES FROM THE UPPER SILESIAN REGION
}

\author{
Anna KOCHMAŃSKA \\ Silesian University of Technology; Anna.Kochmanska@ polsl.pl, ORCID: 0000-0002-6243-8687
}

\begin{abstract}
The issues related to the functioning of multicultural teams are the focus of widespread contemporary discussions, all due to the changes taking place on the contemporary labour market, which determine their emergence. In order to take full advantage of the potential of a multicultural team, it is necessary to integrate it and solve potential problems which are determined by its diversity. Therefore, the main aim of the article is to characterise the contemporary problems which occur in multicultural teams, based on the opinions of employees from the Upper Silesian region. Suggestions as to how they should be resolved will be further presented.
\end{abstract}

Keywords: cultural diversity management, multicultural teams, problems occurring in multicultural teams.

\section{Introduction}

Analysing the situation on the Polish labour market, one is certainly bound to identify many significant transformations which have taken place. First of all, the situation of employees has changed in connection with the major development of the economy - constantly decreasing unemployment and continually growing demand for human resources resulted in more rights being vested in employees, and in better job opportunities.

Moreover, in connection with Poland's accession to the EU, our country was obliged to adopt the European Employment Strategy (Drela, 2009). Therefore, the principle of free movement of persons (related to the possibility of each EU member state inhabitant to choose the country, in which they want to work) entered into force as well (Drela, 2009). The EES pillars are presented in Table 1. 
Table 1

Pillars of the European Employment Strategy

\begin{tabular}{|c|c|}
\hline Pillar 1 & Pillar 2 \\
\hline $\begin{array}{l}\text { Measures taken to increase the chances of } \\
\text { employment: } \\
\text { - preparation of information programs, } \\
\text { - training programmes dedicated to the unemployed, } \\
\text { - cooperation of diverse training } \\
\text { institutions, } \\
\text { - emphasis on vocational education for people entering } \\
\text { the labour market. }\end{array}$ & $\begin{array}{l}\text { Measures aimed at supporting entrepreneurship: } \\
\text { - reducing labour costs, } \\
\text { - creating systems which stimulate self-employment, } \\
\text { - promoting employment through the development of } \\
\text { social non-governmental institutions, } \\
\text { - reducing administrative costs. }\end{array}$ \\
\hline Pillar 3 & Pillar 4 \\
\hline $\begin{array}{l}\text { Measures which support and stimulate } \\
\text { adaptation: } \\
\text { - supporting training courses organised within various } \\
\text { organisations, } \\
\text {-creating modern forms of work organisation }\end{array}$ & $\begin{array}{l}\text { Developing a policy of equal employment } \\
\text { opportunities } \\
\text { - facilitating re-entry on the labour market, after } \\
\text { a longer period of inactivity, } \\
\text { - counteracting discrimination based on gender, } \\
\text { - creating proper working conditions for people with } \\
\text { disabilities }\end{array}$ \\
\hline
\end{tabular}

Drela, K. (2009). European Employment Strategy and the free movement of persons. In A.P. Balcerzak. (Eds.), Polski rynek pracy w warunkach integracji europejskiej (p.93). Toruń: Wydawnictwo Adam Marszałek.

Due to such favorable conditions for job seekers, which are presented above, a high tendency to create multicultural teams has been recorded. In order to use the potential of such a team and the associated opportunity to learn other cultures (Kowalczyk, 2015), it is necessary to solve current problems which emerge in such a team.

Therefore, the main aim of the article is to characterise the contemporary problems which occur in multicultural teams, based on the opinions of employees from the Upper Silesian region. Suggestions as to how they should be resolved will be further presented.

\section{Cultural diversity - an overview}

Cultural diversity management can be defined as "an active phenomenon which involves leading and coordinating organisational diversity in a way that ensures that the strategic objectives of the organisation are achieved. Its purpose is therefore to ensure that employees from different cultural backgrounds can make their own contribution to achieving these objectives" (Mazur, 2010, p. 127).

The role of the superior is of key importance here, as they should not rely on traditional, conventional management styles, but rather prefer transformational leadership. It is based on the fact that "the leader transforms the consciousness of the people they lead, and those people, through their reactions, transform the consciousness of the leader" (Trompenaars, and Hampden-Turner, 2005, p. 162). 
The leader must also be aware that the process of diversity management should be approached holistically, at the level of four organisational processes: interactive, motivational, visionary or learning (Mazur, 2009, p.75).

The motivational process is related to increasing the degree of employee involvement. In order to do this, attention should be paid to the communication system. Additionally, the leader should share information about successes and failures with the team (Mazur, 2009).

The process of interaction, in turn, "enables different groups of employees to gradually create a common set of meanings and to develop a commonly accepted thought process common mental models" (Mazur, 2009).

The process of creating a vision is also very important. This is a huge challenge for management as it requires the support of a culturally diverse group in order to bridge individual differences among the employees (Mazur, 2009).

The last of the aforementioned processes, learning, is based not only on effective knowledge acquisition, but also on the ability to share competences (Mazur, 2009). It is also worth remembering that the multicultural team itself is a great repository of knowledge and being its member may prove to be very a valuable experience for its participants (in terms of acquiring not only knowledge about another cultures, but also learning tolerance or acceptance of differences).

In order for all the above mentioned processes to run properly and to be successful, it is necessary to pay special attention to proper communication in a culturally diverse team. By personalising the message (formulating it in first person singular), it is possible to include a lot of key information about a person's value system, their needs and expectations towards the message recipient (Oppermann, and Webber, 2009).

This is the only way cultural stereotypes, described as "existing images of a given culture", can be overcome. Members of this culture are the subjects of these stereotypes. Stereotypes often create an involuntary image (set of beliefs and values) of a given culture among other societies (cultures)" (Bartosik-Purgat, 2006 p. 27).

The role of communication in cultural diversity management is also vividly described by the authors W.B. Gudykunst and Y.Y. Kim, who emphasise that "culture and communication are so closely linked that culture is communication and communication is culture. In other words, we communicate with each other in specific ways because we were brought up in a particular culture and adopted its language, principles and norms. However, because we learn the language and these principles and norms of our culture very early on, we generally do not realise how culture forms the whole of our behaviour, especially communication" (Gudykunst, and Kim, 2005, p. 497).

At this point, some measures which help eliminate potential barriers to communication should be indicated. 
First of all, four key strategies can be helpful here: adaptation (i.e. recognition of cultural differences and an attempt to adapt to them), structural changes (reorganisation of multicultural teams), intervention of the manager (by setting clear rules at the beginning of the team work or their significant involvement in crisis situations), and exclusion of team members who cannot acclimatise (Bret, Bahfar, and Kern, 2006).

\section{Problems occurring in multicultural teams and methods to resolve them}

As mentioned earlier, a multicultural team has a huge potential (due to its varied experience, differing approaches to the duties performed and undoubted creativity). However, this diversity, which is a source of innovative solutions, can be a cause of many complex problems at the same time. They can be divided into two main groups according to the reasons for their occurrence. The first of them includes the problems, the origins which are related to the specificity of the functioning of a multicultural group. The most prominent issues here are (Wziątek-Staśko, 2012):

- problems with adaptation to the organisation (its culture, the prevalent norms and values which are considered a priority for the organisation, working methods, employees, management style),

- the pursuit of one's own interests and neglecting the common good,

- high level of employee claims,

- the risk of the so-called subgroups being formed, which gives rise to a real organisational pathologies, such as mobbing, for example,

- immense demands of multicultural teams for the management staff,

- lack of knowledge of the multicultural team members about the concept of diversity itself, its main assumptions, the rules of functioning within the team, which can lead to many conflict situations,

- integration problems due to cultural differences,

- prejudices towards the members of multicultural teams, often caused by stereotypical ideas about other cultures.

The second group of problems is related to the inappropriate attitude of managers who are unskilled in managing a culturally diverse group.

These may include, among others (Wziątek-Staśko, 2012):

- low group effectiveness due to an inappropriate management style (emphasising shortterm goals only, also due to low knowledge of team diversity and the related requirements), 
- favouring certain workers. Many members of multicultural teams complain about these situations, which leads to the strengthening of mutual prejudices and to conflict situations which are sometimes very difficult to resolve,

- misunderstanding of the superior's orders, resulting from improper communication with the team, which, as already mentioned, is the key to the effective management of a multicultural team,

- lack of possibility to prove one's skills due to the absence of delegation of powers. This situation is caused by a lack of trust in employees, which may result in stagnation and frustration of team members who want to be creative and be appreciated for their work and their creative approach,

- lack of acceptance of existing norms and values (existing organisational culture), which contributes to the growing lack of trust within the organization and disintegration of the group,

- inadequate motivation system, unfit for the requirements of the team.

Analysing the numerous problems which may potentially arise among culturally diverse groups of employees that, what is noteworthy, affect the effectiveness of the team to a very large extent, one should also consider the ways, in which they could be effectively counteracted. A successful solution may be to organise orientation meetings, during which participants may get to know each other much better. It is also important to emphasise comprehensive diversity training for employees and managers, organised on a regular basis (Kostera, and Śliwa, 2010).

Furthermore, it is a good idea to assign mentors to newly recruited employees to familiarise them with the organisational culture and to present them simultaneously with two key dimensions: organisational (familiarising them in detail with their responsibilities) and social (introducing them to the group). This is particularly important, since a smart intervention will help eliminate stereotypes, prejudices, and will shape good relations in the group, which, in turn, may significantly improve the effectiveness of the activities performed.

\section{Analysis of the study results}

The pilot study was conducted among the employees of organisations operating in the Silesian Voivodeship in May and June 2019. The research methods applied included diagnostic survey, a questionnaire, and the research tool used was a questionnaire (consisting of 5 close ended questions and a metric). The reason for selecting this research method was the possibility of surveying a larger group of respondents in a relatively short time. The sampling was random. The research tool was delivered directly to the respondents. 
142 respondents (including 86 women and 56 men) took part in the study. Most of them have higher education $(52.11 \%), 34.50 \%$ have secondary education and $13.38 \%$ have vocational education. The largest number of respondents (as many as $41.54 \%$ ) were aged 35-44, followed by respondents aged 25-34 (30.98\%). Respondents aged up to 24 years constituted $22.22 \%$ of the studied population, and $4.92 \%$ were respondents aged 45-54. Analysing the respondents in terms of job tenure, the largest group were those who worked from 11 to 15 years (34.50\%). They were followed by employees with 6-10 years of work experience $(33.09 \%)$, 0-5 years of work experience $(25.32 \%)$ and over 15 years of work experience $(7.04 \%)$. All respondents were working in non-executive positions.

An analysis of the survey questions is presented below.

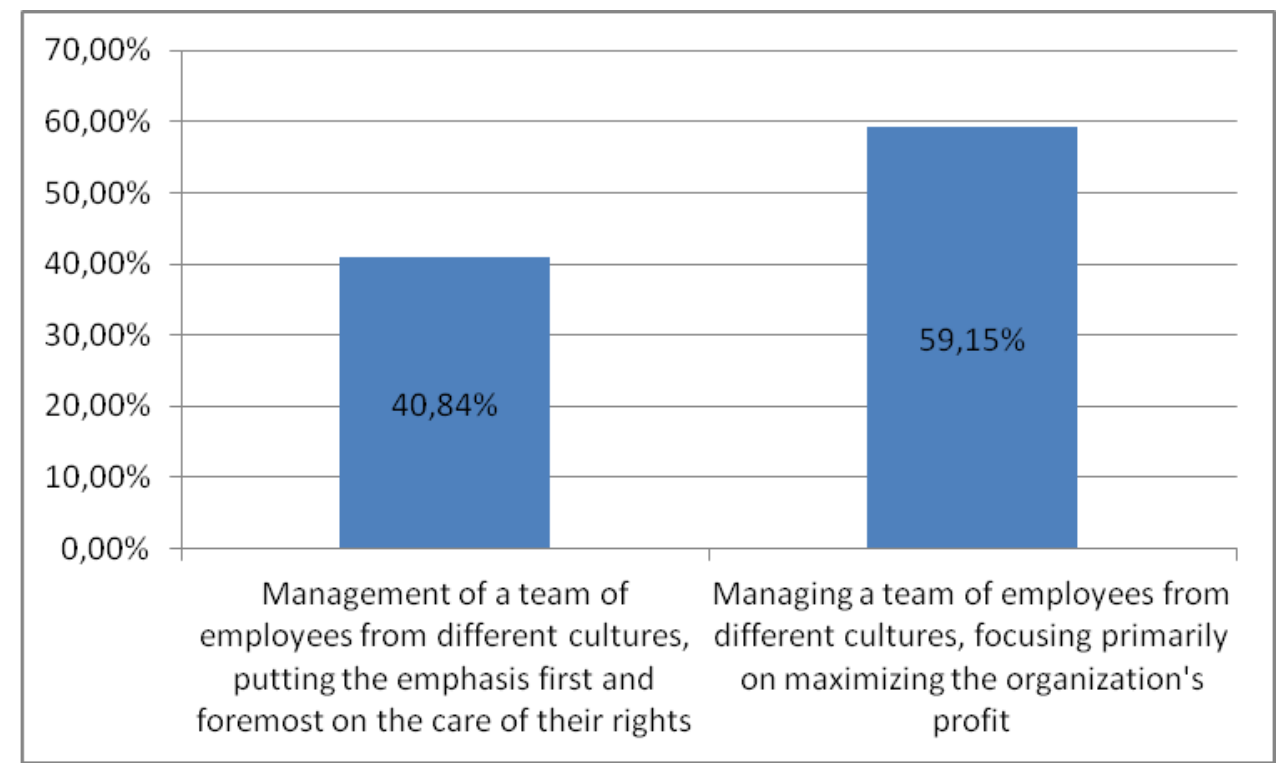

Figure 1. The way respondents perceive the term "cultural diversity management". Source: own study.

The first question respondents were asked in the survey was related to their perception of the concept of "cultural diversity management". According to the above diagram, most of respondents (59.15\%) identified them with the management of a team of employees originating in different cultures, which emphasises the benefit for the organisation. Perhaps this perception of the concept is related to their own experience and the attitude of the managers. $40.84 \%$ of respondents, on the other hand, have a completely different perception of the concept - they believe that the issue is mainly based on managing a culturally diverse team of workers in such a way that their rights are respected first. Such actions certainly contribute to the greater effectiveness of the multicultural team and creating attitudes of associating employees with the organisation. 


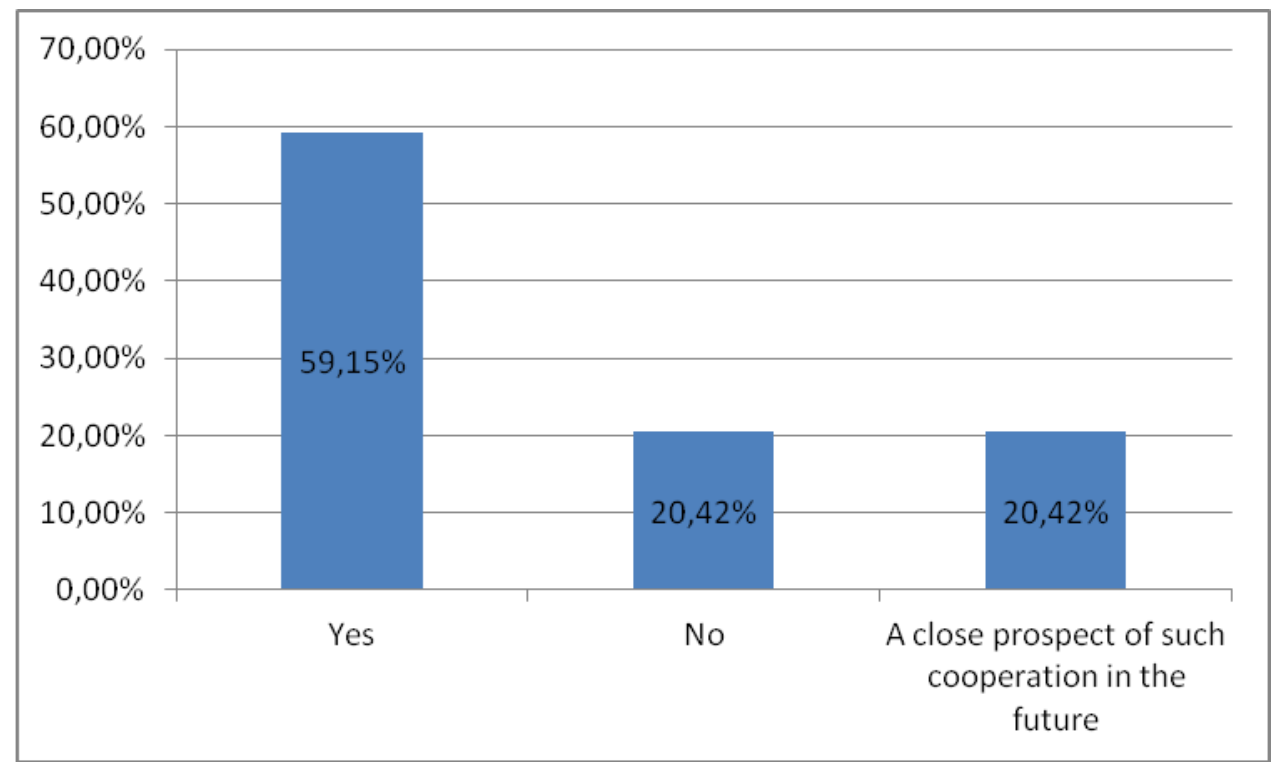

Figure 2. Cooperation of respondents in multicultural teams. Source: own study.

The next question respondents were asked, concerned their cooperation within multicultural teams. The vast majority of them (as many as 59.15\%) have worked in such groups. $20.42 \%$ of respondents have not experienced multicultural cooperation yet. In turn, $20.42 \%$ of respondents are expecting to be part of such cooperation in the foreseeable future. As mentioned earlier, this trend is related to the process of globalisation and the possibility of free movement of EU citizens. That is why it is so important to define clear rules for such cooperation and to create conditions for the continuous self-improvement of employees in order to take advantage of the vast potential that lies in a multicultural team.

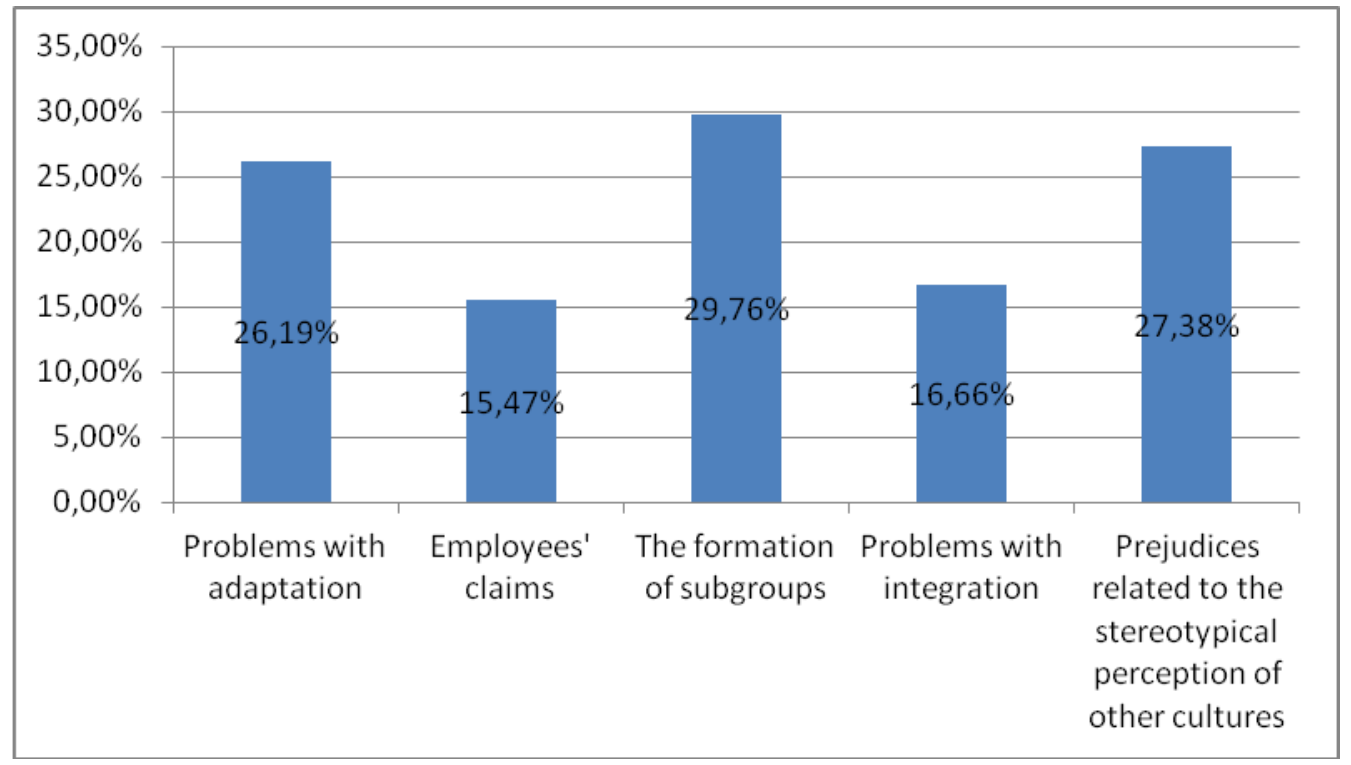

Figure 3. Problems occurring in multicultural groups, in a breakdown into their specific nature. Source: own study. 
Respondents who, in question no. 2, declared that they cooperated or still cooperate in multicultural teams, were asked about the problems they most frequently encountered in the course of such cooperation (it should be stressed that the specific character of a multicultural team was adopted as the basis). Respondents were able to choose all the alternatives available. The analysis of the responses indicated that the most common problem is the formation of the so-called subgroups (29.76\% of indications). They can compete with each other, which may pose obstacles to the joint, conflict-free pursuit of the organisation's goals. Prejudice caused by stereotypical perception of other cultures (27.38\% of indications) was ranked second. Unfortunately, it is quite a common phenomenon, and overcoming stereotypical thinking is a long-term process which requires a huge effort on the part of managers. Further on, respondents indicated adaptation problems (26.19\%), problems with integration $(16.66 \%)$ and a demanding attitude of the employees (15.47\%). Although the demanding attitude was the least common problem, it should not be underestimated, as failure to meet their main needs may lead to a split in the group.

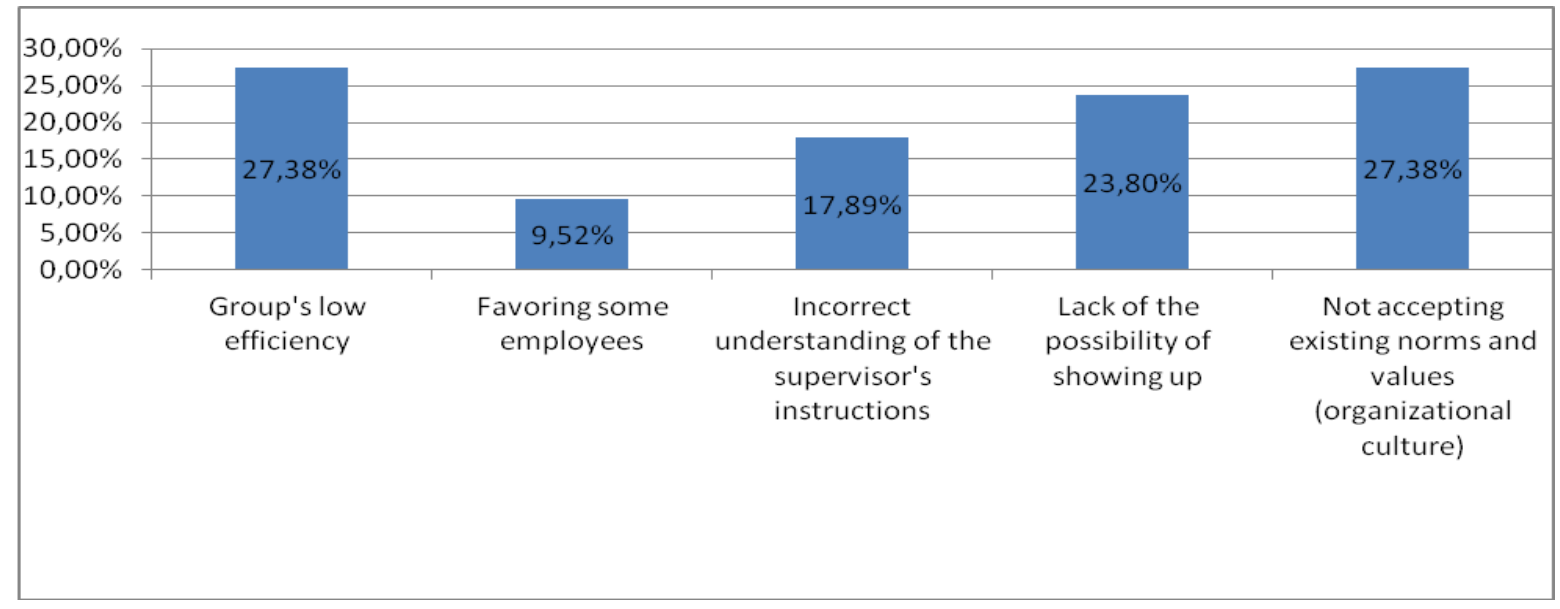

Figure 4. Problems occurring in multicultural teams, in a breakdown into mistakes made by the management. Source: own study.

Respondents who in, question no. 2, declared that they cooperated or still cooperate in multicultural teams, were also asked about the problems they most frequently encountered in the course of such cooperation, resulting from mistakes made by the management. As mentioned before, they are related to an inappropriate management style, improper communication with the team, lack of trust in employees or inadequate motivation system. As in question no. 3, they could choose all of the alternatives available.

An analysis of the responses indicated that two key problems claimed to have been the most frequent were low group effectiveness (understood as the ability to successfully complete assumed tasks) and the lack of acceptance of the organisational culture (27.38\% of indications). Furthermore, respondents pointed to: the lack of ability to prove oneself $(23.80 \%)$, misunderstanding of the superior's orders $(17.89 \%)$ and favouring some employees $(9.52 \%)$. 


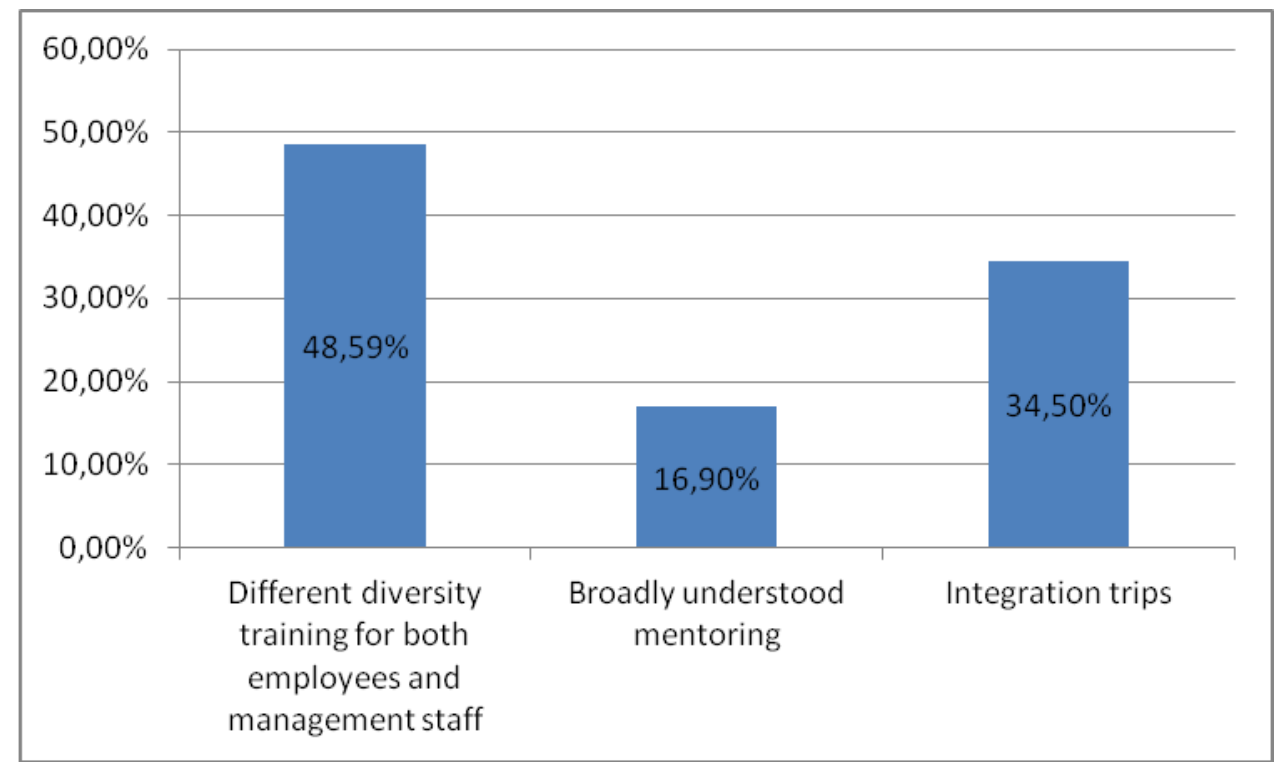

Figure 5. Suggestions for resolving problems occurring in multicultural teams. Source: own study.

Due to the importance of the problems identified by respondents, which undoubtedly cause disturbances in the functioning of a multicultural team (leading to its split in extreme cases), respondents were also asked to suggest one way of resolving them. All respondents participating in the survey were asked to respond. According to them, the most viable solution involved diverse trainings for both employees and managers in the field of diversity ( $48.58 \%$ of responses). They provide a better understanding of the issue, and will be the key to overcoming stereotypical thinking, thus contributing to a better cooperation within the group. Corporate team building trips $(34.50 \%)$ are also of educational and cognitive value. Broadly understood mentoring $(16.90 \%)$ was mentioned last.

\section{Conclusions}

Multicultural teams are the subject of many studies, due to their increasingly common presence in organisations operating on the Polish market. It is noteworthy that many employees have already experienced such cooperation or are expected to experience it in the foreseeable future.

In order for multicultural teams to be able to effectively implement the objectives set in the organisation, it is necessary to eliminate serious problems which may occur in them. The analysis indicated that, in a multicultural team, problems can develop on two levels, i.e. as a result of a specific nature of the team, and at the default of the management. However, regardless of the cause of their occurrence, it is necessary to look for effective ways to resolve them in order to unlock the immense potential lying in multicultural cooperation. 


\section{References}

1. Bartosik-Purgat, M. (2006). Otoczenie kulturowe w biznesie międzynarodowym. Warszawa: PWE.

2. Brett, J., Bahfar, K., Kern, M.C. (2006). Managing Multicultural Teams. In: J. Szaban. (Ed.), Zachowania organizacyjne. Aspekt międzykulturowy (p. 88-89). Toruń: Wydawnictwo Adam Marszałek.

3. Drela, K. (2009). Europejska Strategia Zatrudnienia a swobodny przepływ osób. In: A.P. Balcerzak (Ed.), Polski rynek pracy w warunkach integracji europejskiej (p. 93). Toruń: Wydawnictwo Adam Marszałek.

4. Gudykunst, W.B., Kim, Y.Y. (2005). Komunikowanie się z obcymi: spojrzenie na komunikację międzykulturową. In: J. Stewart (Ed.), Mosty zamiast murów. Podręcznik komunikacji interpersonalnej (p. 497). Warszawa: PWN.

5. Kostera, M., Śliwa, M. (2010). Zarzadzanie w XXI wieku: jakość, twórczość, kultura. Warszawa: Wydawnictwa Akademickie i Profesjonalne.

6. Kowalczyk, A.Z. (2015). Zespoły wielokulturowe-wyzwanie współczesnych organizacji. Organizacja i Zarzadzanie, 60, 99.

7. Mazur, B. (2009). Zarządzanie w warunkach różnorodności zasobów ludzkich. Białystok: Wydawnictwo Wyższej Szkoły Finansów i Zarządzania.

8. Mazur, B. (2010). Zarządzanie zróżnicowaniem kulturowym przedsiębiorstw Podlasia. Współczesne Zarządzanie, 1, 127.

9. Oppermann, K., Webber, E. (2007). Style porozumiewania się w pracy. Gdańsk: Gdańskie Wydawnictwo Psychologiczne.

10. Trompenaars, F., Hampden-Turner, Ch. (2005). Zarzadzanie personelem w organizacjach zróżnicowanych kulturowo. Kraków: Oficyna Ekonomiczna.

11. Wziątek-Staśko, A. (2012). Diversity management. Narzędzie skutecznego motywowania pracowników. Warszawa: Difin. 